\title{
RELATIONSHIPS BETWEEN GRAIN YIELD AND ACCUMULATION OF BIOMASS, NITROGEN AND PHOSPHORUS IN COMMON BEAN CULTIVARS ${ }^{(1)}$
}

\author{
Adelson Paulo Araújo ${ }^{(2)} \&$ Marcelo Grandi Teixeira ${ }^{(3)}$
}

\begin{abstract}
SUMMARY
Shoot biomass is considered a relevant component for crop yield, but relationships between biological productivity and grain yield in legume crops are usually difficult to establish. Two field experiments were carried out to investigate the relationships between grain yield, biomass production and $N$ and $P$ accumulation at reproductive stages of common bean (Phaseolus vulgaris) cultivars. Nine and 18 cultivars were grown on $16 \mathrm{~m}^{2}$ plots in 1998 and 1999 , respectively, with four replications. Crop biomass was sampled at four growth stages (flowering R6, pod setting R7, beginning of pod filling R8, and mid-pod filling R8.5), grain yield was measured at maturity, and $N$ and $P$ concentrations were determined in plant tissues. In both years, bean cultivars differed in grain yield, in root mass at $R 6$ and $R 7$ stages, and in shoot mass at $R 6$ and $R 8.5$, whereas at $R 7$ and $R 8$ differences in shoot mass were significant in 1998 only. In both years, grain yield did not correlate with shoot mass at $R 6$ and $R 7$ and with root mass at R6. Grain yield correlated with shoot mass at R8 in 1999 but not in 1998, with shoot mass at R8.5 and with root mass at $R 7$ in both years. Path coefficient analysis indicated that shoot mass at R8.5 had a direct effect on grain yield in both years, that root mass at $R 7$ had a direct effect on grain yield in 1998, and that in 1999 the amounts of $\mathrm{N}$ and $\mathrm{P}$ in shoots at $\mathrm{R} 8.5$ had indirect effects on grain yield via shoot mass at R8.5. A combined analysis of both experiments revealed that biomass accumulation, $N$ and $P$ in shoots at $R 6$ and $R 7$ as well as root mass at R6 were similar in both years. In 1998 however bean accumulated more root mass at R7 and more biomass and $N$ and $P$ in shoots at $R 8$ and R8.5, resulting in a $57 \%$ higher grain yield in 1998. This indicates that grain yield of different common bean cultivars is not intrinsically associated with vegetative vigor at flowering and that
\end{abstract}

\footnotetext{
(1) Recebido para publicação em setembro de 2007 e aprovado em agosto de 2008.

(2) Professor do Departamento de Solos, Universidade Federal Rural do Rio de Janeiro - UFRRJ. CEP 23890-000 Seropédica (RJ). Bolsista do CNPq. E-mail: aparaujo@ufrrj.br

(3) Embrapa Agrobiologia. CEP 23890-000 Seropédica (RJ). E-mail: grandi@cnpab.embrapa.br
} 
mechanisms during pod filling can strongly influence the final crop yield. The establishment of a profuse root system during pod setting, associated with the continuous $\mathrm{N}$ and $\mathrm{P}$ acquisition during early pod filling, seems to be relevant for higher grain yields of common bean.

Index terms: common bean, genotype, ontogeny, Phaseolus vulgaris, plant growth, root.

\title{
RESUMO: RELAÇÕES ENTRE O RENDIMENTO DE GRÃOS E A ACUMULAÇÃO DE BIOMASSA, NITROGÊNIO E FÓSFORO EM CULTIVARES DE FEIJOEIRO
}

\begin{abstract}
A biomassa de parte aérea é considerada um componente relevante para o rendimento dos cultivos, mas é usualmente difícil estabelecer relações entre produção biológica e rendimento de grãos em leguminosas. Foram realizados dois experimentos de campo com o objetivo de investigar as relações entre o rendimento de grãos, a produção de biomassa $e$ a acumulação de $N$ e $P$ em estádios reprodutivos de cultivares de feijoeiro (Phaseolus vulgaris). Nove e 18 cultivares foram cultivadas em 1998 e 1999, respectivamente, em parcelas de $16 \mathrm{~m}^{2}$ com quatro repetições. A biomassa foi amostrada em quatro estádios (floração $R 6$, emissão de vagens $R 7$, início de enchimento de vagens $R 8$ e meio de enchimento de vagens $R 8,5$ ), o rendimento de grãos mensurado na maturação, e foram medidas as concentrações de $N$ e $P$ nos tecidos vegetais. Nos dois anos, as cultivares de feijoeiro diferiram no rendimento de grãos, na massa de raízes nos estádios $R 6$ e $R 7$ e na massa de parte aérea em $R 6$ e $R 8,5$, porém em $R 7$ e $R 8$ apenas em 1998 houve diferenças na massa de parte aérea. Nos dois anos, o rendimento de grãos não se correlacionou com a massa de parte aérea em $R 6$ e $R 7$ e com a massa de raízes em $R 6$. O rendimento de grãos correlacionouse com a massa de parte aérea em $R 8$ em 1999, com a massa de parte aérea em $R 8,5$ e com a massa de raízes em $R 7$ nos dois anos. Análises de trilha indicaram que a massa de parte aérea em $R 8,5$ exerceu efeito direto no rendimento de grãos nos dois anos, que a massa de raízes em $R 7$ teve efeito direto no rendimento em 1998 e que em 1999 a acumulação de $N$ e $P$ na parte aérea em $R 8,5$ teve efeito indireto no rendimento via massa de parte aérea em $R 8,5$. A análise conjunta dos dois experimentos revelou que a acumulação de massa, $N$ e $P$ na parte aérea em $R 6$ e $R 7$, assim como a massa de raízes em $R 6$, foram similares nos dois anos, mas em 1998 o cultivo acumulou mais massa de raízes em $R 7$ e mais massa, $N$ e $P$ na parte aérea em $R 8$ e R8,5, o que resultou em produção de grãos 57 \% superior em 1998 . Isso indica que o rendimento de grãos de cultivares de feijoeiro não está intrinsecamente associado com o vigor vegetativo na floração e que mecanismos operantes durante o enchimento das vagens podem influenciar acentuadamente a produção de grãos. $O$ estabelecimento de um profuso sistema radicular durante a emissão de vagens, associado com a contínua aquisição de $N$ e $P$ durante o início de enchimento de vagens, pode assumir relevância para obtenção de maiores rendimentos de grãos na cultura do feijão.
\end{abstract}

Termos de indexação: feijão, genótipo, ontogenia, Phaseolus vulgaris, crescimento vegetal, raiz.

\section{INTRODUCTION}

Common bean (Phaseolus vulgaris L.) represents a staple legume in many developing countries, but bean productivity is usually very low in most countries in Latin America and Africa, which requires agronomic and breeding efforts to improve grain yields. Selection for yield and morphological traits, such as resistance to biotic and abiotic stresses, plant architecture, growth habit and maturity, has been pursued by breeders to develop bean cultivars with superior performance or better adapted to specific environments, but complex inheritance patterns and strong environmental effects can limit the genetic selection of these traits (Tar'an et al., 2002).

Improved cereal yields have been achieved in the last decades by increased or extended photosynthesis per unit land area, through irrigation and with improved agronomic practices such as fertilizer application, and also by increased partitioning of crop biomass to the harvested product (Richards, 2000). However, unlike self-pollinated cereals, where improved biomass partitioning has attained higher grain yields, the breeding progress for grain yield in 
common bean has been relatively modest (Kelly et al., 1998). Moreover, the inherently higher energy costs associated with the production of protein-rich legume seeds may limit future gains in productivity (Munier-Jolain \& Salon, 2005).

Yan \& Wallace (1995) proposed that the shoot biomass, harvest index, and days to grain maturity are the three major physiological-genetic components for crop yield accumulation. Two main features were considered for the selection for higher yield in common bean: some lines with a longer cycle that have a high biomass accumulation, and some lines with shorter cycles and higher harvest indices and, thus, a more effective biomass partitioning (Scully \& Wallace, 1990). The measurement of shoot biomass at flowering, underlying the rate of biomass accumulation across the vegetative and the reproductive stages, improves the understanding of the physiology of crop yield. Furthermore, it indicates the relative importance of the vegetative biomass for the potential yield capacity and the proportion of this biomass that is subsequently remobilized to the reproductive organs (Yan \& Wallace, 1995).

Remobilization of nutrients such as $\mathrm{N}$ and $\mathrm{P}$ from vegetative tissues to reproductive organs plays an important role for legume grain yield. As revised by Schiltz et al. (2005), the contribution of $\mathrm{N}$ remobilization for seed $\mathrm{N}$ demand varies from $70 \%$ in field-grown peas, 80 to $90 \%$ in soybean, 43 to $94 \%$ in lentil, $84 \%$ in common bean, and $80 \%$ in faba bean. Bean pods and seeds were major sinks for $\mathrm{N}$ when applied at vegetative and reproductive stages, respectively (Westermann et al., 1985), and $\mathrm{N}$ allocation to seeds dominates the reproductive $\mathrm{N}$ budget of common bean (Lynch \& White, 1992). Leaf remobilization also supplied over half of the pod plus seed P in pot-grown bean plants (Snapp \& Lynch, 1996). Indeed, values of $N$ and $P$ harvest indices were much greater than values of biomass harvest index in common bean cultivars, denoting that the translocation of $\mathrm{N}$ and $\mathrm{P}$ to the seeds is more intense than of photosynthates (Araújo \& Teixeira, 2003).

However, it has been difficult to define the relationships between biological productivity and grain yield in legume crops (Stone \& Pereira, 1994). Although grain yield can be related to leaf area duration and shoot mass within the same common bean cultivar (Laing et al., 1984; Stone \& Pereira, 1994), bean shoot biomass of different cultivars did not correlate with grain yield at any $\mathrm{P}$ level applied to the soil (Yan et al., 1995; Araújo et al., 2000), indicating that the relationship between vegetative vigor and yield did not apply to the different genotypes. Notwithstanding, the identification of a specific period of crop development, regarded as critical for crop establishment, could indicate appropriate agronomic practices for maximizing crop yield. Therefore, more detailed studies on the relationship between shoot growth, nutrient accumulation and grain yield of bean genotypes are required, which could allow the genetic selection for yield potential and nutritional efficiency during vegetative growth stages or at the beginning of the reproductive development. The purpose of this study was to investigate the relationships between grain yield, biomass production and accumulation of $\mathrm{N}$ and $\mathrm{P}$ at reproductive stages in field-grown common bean cultivars.

\section{MATERIALS AND METHODS}

Two field experiments were carried out in the experimental area of Embrapa Agrobiologia, in Seropédica, Brazil (22 $45^{\circ} \mathrm{S}$; $43^{\circ} 42^{\prime} \mathrm{W}$; ca. $40 \mathrm{~m}$ asl). Nine and 18 common bean (Phaseolus vulgaris L.) cultivars were grown in a randomized block design with four replicates, respectively, in May/August 1998 and May/August 1999. Growth habits and seed sizes of the chosen genotypes were different, and their maturity ranged from 71 to 84 days after seed emergence (Table 1).

In the 0-20 cm layer, the Typic Haplustult soil with a sandy clay loam texture contained: $19 \mathrm{mmol}_{\mathrm{c}} \mathrm{kg}^{-1} \mathrm{Ca}, 15 \mathrm{mmol}_{\mathrm{c}} \mathrm{kg}^{-1} \mathrm{Mg}, 1.8 \mathrm{mmol}_{\mathrm{c}} \mathrm{kg}^{-1}$ $\mathrm{K}, 1 \mathrm{mmol}_{\mathrm{c}} \mathrm{kg}^{-1} \mathrm{Al}, 12 \mathrm{mmol}_{\mathrm{c}} \mathrm{kg}^{-1} \mathrm{H}, 3 \mathrm{mg} \mathrm{kg}-1$ available $\mathrm{P}, 6.9 \mathrm{~g} \mathrm{~kg}^{-1}$ organic $\mathrm{C}$, and water $\mathrm{pH} 4.9$. Each $16 \mathrm{~m}^{2}$ plot had eight $4-\mathrm{m}$ rows spaced $0.5 \mathrm{~m}$ apart (Figure 1). Commercial fertilizer was applied along the rows at a rate of $25 \mathrm{~kg} \mathrm{ha}^{-1} \mathrm{~N}, 40 \mathrm{~kg} \mathrm{ha}^{-1} \mathrm{P}$ and $40 \mathrm{~kg} \mathrm{ha}^{-1} \mathrm{~K}$. The sowing density of 30 seed $\mathrm{m}^{-2}$ resulted in a final stand at maturity, averaged across cultivars, of 27.7 plant $\mathrm{m}^{-2}$ in both years. In 1998, no additional $\mathrm{N}$ was supplied to the crop, since green manure with Crotalaria juncea was incorporated to the soil two months before planting, whereas in 1999 $30 \mathrm{~kg} \mathrm{ha}^{-1} \mathrm{~N}$ was applied as urea 30 days after emergence. Due to rust (Uromyces phaseoli) symptoms in 1999, a fungicide was applied 49 days after emergence and the disease was properly controlled. The experiments were irrigated weekly. Climatic conditions during the experiments were, in 1998 and 1999, respectively: mean temperature 19.4 and $19.6{ }^{\circ} \mathrm{C}$, relative humidity 63 and $66 \%$ and pan evaporation 3.1 and $2.7 \mathrm{~mm}_{\text {day }^{-1}}$.

Crop biomass was sampled at four stages of plant development: full flowering (R6), pod setting (R7), beginning of pod filling (R8), and mid-pod filling (R8.5), according to Fernández et al. (1985). An almost constant interval between sampling dates was maintained (Table 1). The sample unit consisted of plants harvested from $1 \mathrm{~m}$ of the second or seventh row of each plot (Figure 1). Shoots (including pods) were harvested at the ground level, and at R6 and R7 stages roots were sampled by hoeing along the rows at the ploughed soil depth of $0-20 \mathrm{~cm}$. Although root recovery was restricted to the $0-20 \mathrm{~cm}$ layer, the clay B horizon of the experimental area limited deeper root growth. Roots were carefully washed under running 
Table 1. Some characteristics and sampling dates of common bean cultivars evaluated in two field experiments (1998 and 1999)

\begin{tabular}{|c|c|c|c|c|c|c|c|}
\hline \multirow{2}{*}{ Cultivar } & \multirow{2}{*}{ Growth habit $^{(1)}$} & \multirow{2}{*}{100 seed mass } & \multicolumn{5}{|c|}{ Stage of sampling ${ }^{(2)}$} \\
\hline & & & R6 & R7 & R8 & R8.5 & R9 \\
\hline & \multicolumn{7}{|c|}{$\mathrm{g}$} \\
\hline & \multicolumn{7}{|c|}{1998} \\
\hline Goiano Precoce & $\mathrm{ED}$ & 28.9 & 29 & 36 & 43 & 50 & 71 \\
\hline Irai & $\mathrm{ED}$ & 27.2 & 29 & 37 & 45 & 52 & 71 \\
\hline Guapo Brilhante & EI & 17.2 & 37 & 44 & 52 & 59 & 79 \\
\hline Rio Tibagi & EI & 17.4 & 41 & 48 & 55 & 62 & 83 \\
\hline Xamego & EI & 18.3 & 41 & 48 & 55 & 62 & 79 \\
\hline Capixaba Precoce & PI & 23.8 & 30 & 38 & 48 & 56 & 77 \\
\hline Carioca & PI & 23.8 & 41 & 49 & 55 & 62 & 79 \\
\hline Ouro Negro & PI & 22.1 & 36 & 44 & 52 & 59 & 77 \\
\hline \multirow[t]{2}{*}{ Puebla 152} & PI & 23.6 & 41 & 49 & 57 & 65 & 83 \\
\hline & \multicolumn{7}{|c|}{1999} \\
\hline Bolinha & ED & 33.6 & 29 & 36 & 43 & 50 & 74 \\
\hline Constanza & $\mathrm{ED}$ & 61.5 & 33 & 41 & 48 & 56 & 77 \\
\hline Goiano Precoce & $\mathrm{ED}$ & 32.9 & 29 & 36 & 43 & 50 & 71 \\
\hline Irai & ED & 38.3 & 29 & 36 & 43 & 50 & 71 \\
\hline BAT 76 & EI & 15.9 & 41 & 48 & 55 & 62 & 84 \\
\hline Diamante Negro & EI & 22.8 & 39 & 46 & 53 & 60 & 84 \\
\hline Guapo Brilhante & EI & 18.8 & 41 & 48 & 55 & 62 & 84 \\
\hline ICA Pijao & EI & 17.3 & 39 & 46 & 53 & 60 & 84 \\
\hline Manteigão & EI & 37.3 & 33 & 41 & 48 & 56 & 75 \\
\hline Rio Tibagi & EI & 16.2 & 41 & 48 & 55 & 62 & 84 \\
\hline Rosinha & EI & 23.6 & 35 & 43 & 50 & 57 & 75 \\
\hline Safira & EI & 15.8 & 39 & 46 & 53 & 60 & 77 \\
\hline Xamego & $\mathrm{EI}$ & 20.0 & 39 & 46 & 53 & 60 & 83 \\
\hline Aporé & PI & 22.7 & 39 & 46 & 53 & 60 & 82 \\
\hline Capixaba Precoce & PI & 21.7 & 33 & 41 & 48 & 56 & 77 \\
\hline Carioca & PI & 24.7 & 39 & 46 & 53 & 60 & 82 \\
\hline Ouro Negro & PI & 21.0 & 35 & 43 & 50 & 57 & 77 \\
\hline Puebla 152 & PI & 24.1 & 41 & 48 & 55 & 62 & 84 \\
\hline
\end{tabular}

${ }^{(1)}$ Growth habit: ED erect determinate (type I), EI erect indeterminate (type II), PI prostrate indeterminate (type III). ${ }^{(2)}$ R6, R7, R8, R8.5, R9: growth stages of full flowering, pod setting, beginning of pod filling, mid-pod filling, and grain maturity, respectively.

water, and roots and shoots were oven-dried at $65^{\circ} \mathrm{C}$, weighed and ground. At grain maturity, the area of $3 \mathrm{~m}^{2}$ of the two middle rows of each plot was harvested (Figure 1), and the seed yield standardized at $13 \%$ moisture. In shoots and grains, $\mathrm{N}$ concentration was evaluated by the semi-micro Kjeldahl procedure, and $\mathrm{P}$ concentration by nitro-perchloric digestion and the molybdenum-ascorbic acid colorimetric method. The nutrient content in each plant portion was calculated as the product of nutrient concentration and dry mass.

The analysis of variance was initially performed for each experiment and growth stage, evaluating the effect of cultivar. Cultivars were also nested within each growth habit, providing an $\mathrm{F}$ test for significant differences between the three phenological groups. Secondly, since homoscedastic variances were observed in the biomass data from different sampling dates, an analysis of variance was performed for each year to evaluate the effect of growth stages considered as sub-plots of the cultivars, as discussed by Araújo (2003). Thirdly, data from nine cultivars common to

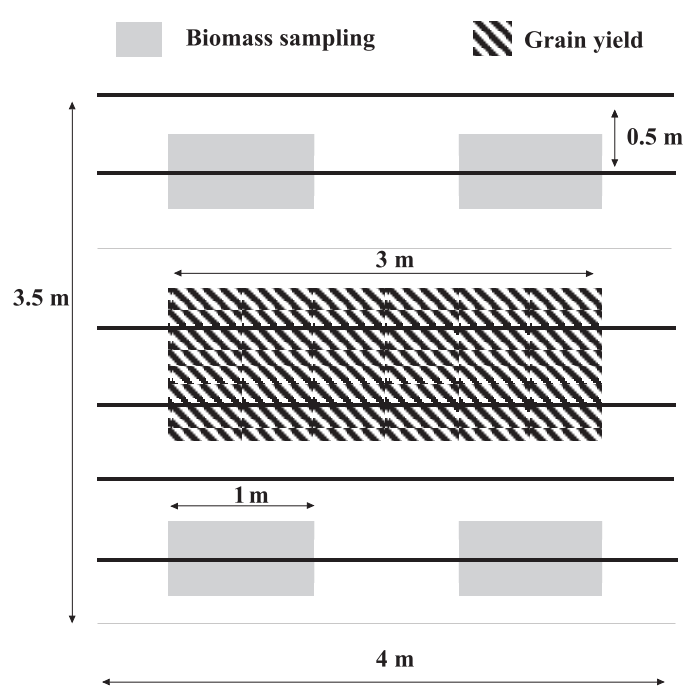

Figure 1. Scheme for biomass sampling and grain yield measurement in field plots with common bean cultivars. 
both experiments were analyzed as one-factor randomized block design combined over years, evaluating the effects of year, cultivar, and their interaction.

In order to investigate the relationships between grain yield and traits of biomass and nutrient accumulation, simple correlation between grain yield and other traits was calculated for each year. Traits with a higher simple correlation with grain yield were included into path coefficient analysis, expressing the direct and indirect effects of each biomass trait on grain yield. The relatively low number of evaluated cultivars hindered the estimates of genetic and environmental correlation among traits.

\section{RESULTS}

Bean cultivars differed in shoot mass at the stages R6 and R8.5 in both years, but at R7 and R8 the differences between cultivars in shoot mass were only significant in 1998 (Table 2). In 1998 the shoot mass of indeterminate cultivars, such as Xamego and Capixaba Precoce, was higher than of determinate cultivars throughout the growth cycle (Table 2 and Figure 2). In contrast, in 1999 the shoot mass of of indeterminate cultivars, such as Carioca and Aporé, was greater at R6 and R7, but at R8.5 the shoot mass of determinate cultivars, such as Iraí and Constanza, was larger (Table 2 and Figure 2). In 1998, shoot mass averaged across cultivars increased continuously from R6 to R8.5 (Table 2). In 1999, shoot mass increased between $\mathrm{R} 6$ and $\mathrm{R} 7$ and between $\mathrm{R} 8$ and R8.5, whereas between R7 and R8 shoot growth ceased, mainly in indeterminate cultivars. Cultivars differed in root mass at R6 and R7 in both years (Table 2). Erect indeterminate cultivars had strong root growth at R6 and R7 in 1998, and also at R6 in 1999, but in 1999 the root mass of determinate cultivars was higher than indeterminate cultivars at R7. Root mass increased after flowering in 1998 but not in 1999 (Table 2).

There were significant differences between cultivars in grain yield in both years: in 1998 the yield ranged from 153 to $206 \mathrm{~g} \mathrm{~m}^{-2}$ for cultivars Carioca and Capixaba Precoce, respectively, and from 87 to $159 \mathrm{~g} \mathrm{~m}^{-2}$ in 1999 for cultivars BAT 76 and Constanza, respectively (Figure 2). In 1999 the grain yield of determinate was higher than of indeterminate cultivars, whereas in 1998 differences between cultivars were more significant within than between phenological groups (Table 2). Average grain yield was 171 and $113 \mathrm{~g} \mathrm{~m}^{-2}$ in 1998 and 1999 , respectively (Table 2), a marked difference between years in terms of yield.

Erect determinate cultivars accumulated more $\mathrm{N}$ in shoots than indeterminate cultivars at R8.5 in both years, and also at R6 in 1998. In the other evaluations, there was no difference in shoot $\mathrm{N}$ content between cultivars (Table 3). In 1998, shoot $\mathrm{P}$ content did not differ between cultivars at $R 6, R 7$ and $R 8$, but at $R 8.5$

Table 2. Shoot mass at four growth stages, root mass at two growth stages, and grain yield at maturity of common bean cultivars grown in two field experiments (1998 and 1999); cultivars were grouped according to growth habit

\begin{tabular}{|c|c|c|c|c|c|c|c|c|}
\hline \multirow{2}{*}{ Growth habit } & \multirow{2}{*}{$\begin{array}{c}\text { Number of } \\
\text { cultivars }\end{array}$} & \multicolumn{4}{|c|}{ Shoot mass } & \multicolumn{2}{|c|}{ Root mass } & \multirow{2}{*}{ Grain yield } \\
\hline & & R6 1 & R7 & R8 & R8.5 & R6 & R7 & \\
\hline & \multicolumn{7}{|c|}{$\mathrm{g} \mathrm{m}^{-2}$} & \\
\hline & \multicolumn{7}{|c|}{1998} & \\
\hline Erect determinate & 2 & $86 \mathrm{~b}$ & $138 \mathrm{~b}$ & $173 \mathrm{~b}$ & $261 \mathrm{~b}$ & $9.0 \mathrm{c}$ & $12.6 \mathrm{~b}$ & $171 \mathrm{a}$ \\
\hline Erect indeterminate & 3 & $142 \mathrm{a}$ & $217 \mathrm{a}$ & $279 \mathrm{a}$ & $271 \mathrm{~b}$ & $16.5 \mathrm{a}$ & $18.0 \mathrm{a}$ & $172 \mathrm{a}$ \\
\hline Prostrate indeterminate & 4 & $150 \mathrm{a}$ & $190 \mathrm{a}$ & $266 \mathrm{a}$ & $303 \mathrm{a}$ & $12.0 \mathrm{~b}$ & $13.6 \mathrm{~b}$ & $171 \mathrm{a}$ \\
\hline Mean & 9 & $133 \mathrm{D}$ & $188 \mathrm{C}$ & $250 \mathrm{~B}$ & $283 \mathrm{~A}$ & $12.8 \mathrm{~B}$ & $14.9 \mathrm{~A}$ & 171 \\
\hline $\mathrm{F}$ test for cultivar & & $9.63^{* * *}$ & $3.55^{* *}$ & $3.45^{* *}$ & $2.30^{*}$ & $9.25^{* * *}$ & $3.32^{* *}$ & $2.32^{*}$ \\
\hline \multirow[t]{2}{*}{$\mathrm{CV}(\%)$} & & 16.66 & 22. 26 & 20.96 & 17.83 & 17.62 & 19.65 & 15.83 \\
\hline & \multicolumn{7}{|c|}{1999} & \\
\hline Erect determinate & 4 & $114 \mathrm{~b}$ & $156 \mathrm{a}$ & $181 \mathrm{a}$ & $230 \mathrm{a}$ & $10.1 \mathrm{~b}$ & $12.3 \mathrm{a}$ & $129 \mathrm{a}$ \\
\hline Erect indeterminate & 9 & $134 \mathrm{a}$ & $162 \mathrm{a}$ & $167 \mathrm{a}$ & $184 \mathrm{~b}$ & $11.8 \mathrm{a}$ & $10.5 \mathrm{~b}$ & $105 \mathrm{~b}$ \\
\hline Prostrate indeterminate & 5 & $134 \mathrm{a}$ & $167 \mathrm{a}$ & $162 \mathrm{a}$ & $180 \mathrm{~b}$ & $9.3 \mathrm{~b}$ & $8.4 \mathrm{c}$ & $115 \mathrm{~b}$ \\
\hline Mean & 18 & $130 \mathrm{C}$ & $162 \mathrm{~B}$ & $169 \mathrm{~B}$ & $193 \mathrm{~A}$ & $10.7 \mathrm{~A}$ & $10.3 \mathrm{~A}$ & 113 \\
\hline F test for cultivar & & $2.37 * *$ & 1.15 & 0.91 & $3.59 * * *$ & $2.60^{* *}$ & $5.89 * * *$ & $4.35^{* * *}$ \\
\hline $\mathrm{CV}(\%)$ & & 20.50 & 21.52 & 21.55 & 19.16 & 20.99 & 18.97 & 15.35 \\
\hline
\end{tabular}

${ }^{(1)}$ R6, R7, R8, R8.5: growth stages of full flowering, pod setting, beginning of pod filling, and mid-pod filling, respectively. For each year, lowercase letters compare growth habits, and capital letters compare growth stages; means followed by the same letter do not differ by the Tukey test $(\mathrm{p}<0.05) .{ }^{*}, * *, * * * \mathrm{~F}$ test significant at $0.05,0.01$ and 0.001 probability levels. 
erect indeterminate cultivars accumulated more $\mathrm{P}$ in shoots. In 1999, determinate cultivars accumulated less $\mathrm{P}$ in shoots at $\mathrm{R} 6$ and $\mathrm{R} 7$, but at $\mathrm{R} 8$ cultivars did not differ in shoot $\mathrm{P}$ content; in R8.5 cultivars differed in shoot $\mathrm{P}$ content within each phenological group. In 1998, shoot $\mathrm{N}$ and $\mathrm{P}$ contents increased continuously from R6 to R8.5 stages (Table 3). In 1999, shoot $\mathrm{N}$ and $\mathrm{P}$ contents increased from R6 to R7, but decreased between R7 and R8, mainly in indeterminate cultivars. In 1999 shoot $\mathrm{N}$ content increased after R8, unlike shoot $\mathrm{P}$ content (Table 3 ). Bean cultivars did not differ in grain $\mathrm{N}$ content in
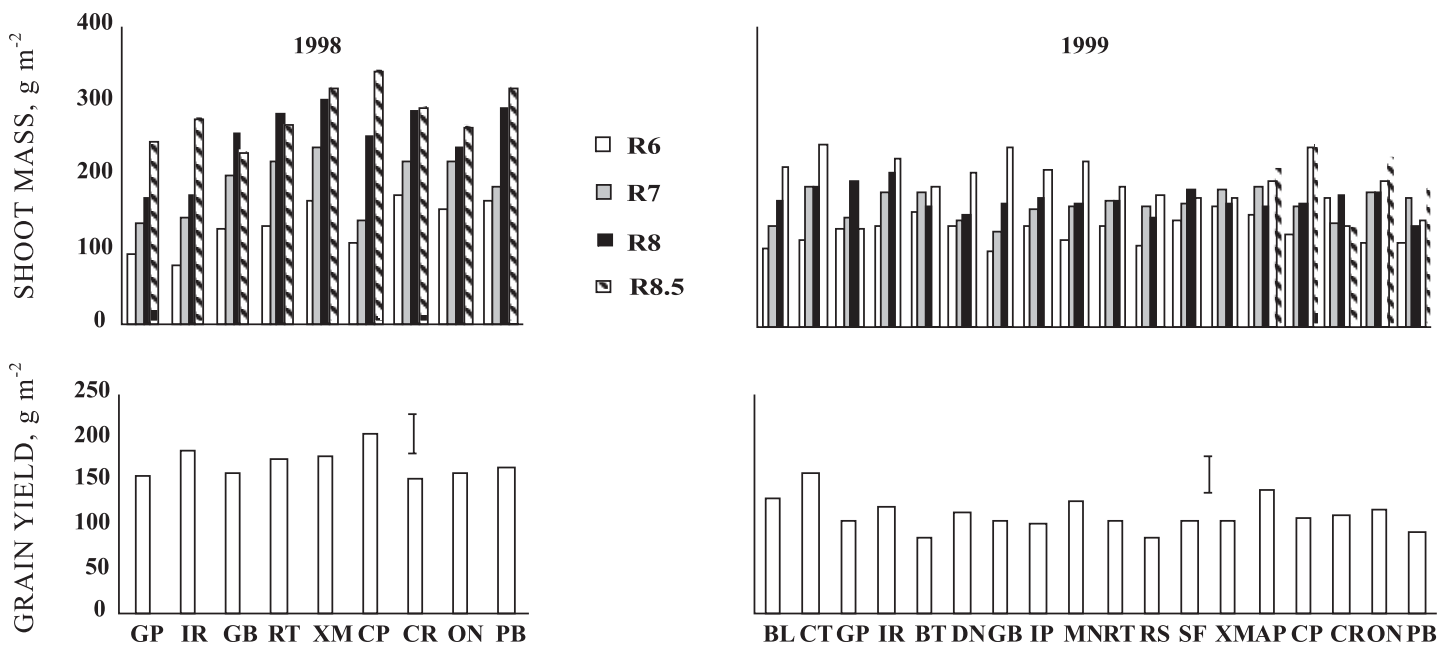

Figure 2. Shoot mass at four growth stages, and grain yield at maturity of common bean cultivars grown in two field experiments (1998 and 1999); means of four replications. R6, R7, R8, R8.5: growth stages of full flowering, pod setting, beginning of pod filling, and mid-pod filling, respectively. Vertical bars represent the least significant difference by Tukey test at $5 \%$ level, and compare grain yields of cultivars. Cultivars: BL Bolinha, CT Constanza, GP Goiano Precoce, IR Iraí, BT BAT 76, DN Diamante Negro, GB Guapo Brilhante, IP ICA Pijao, MN Manteigão, RT Rio Tibagi, RS Rosinha, SF Safira, XM Xamego, AP Aporé, CP Capixaba Precoce, CR Carioca, ON Ouro Negro, PB Puebla 152.

Table 3. Shoot $\mathrm{N}$ and $\mathrm{P}$ contents at four growth stages, and grain $\mathrm{N}$ and $\mathrm{P}$ contents at maturity, of common bean cultivars grown in two field experiments (1998 and 1999); cultivars were grouped according to growth habit

\begin{tabular}{|c|c|c|c|c|c|c|c|c|c|c|}
\hline \multirow{2}{*}{ Growth habit } & \multicolumn{4}{|c|}{ Shoot $N$ content } & \multirow{2}{*}{$\begin{array}{c}\text { Grain } \\
\mathbf{N} \\
\text { content }\end{array}$} & \multicolumn{4}{|c|}{ Shoot $P$ content } & \multirow{2}{*}{$\begin{array}{c}\text { Grain } \\
\mathbf{P} \\
\text { content }\end{array}$} \\
\hline & $\mathrm{R} 6^{(1)}$ & R7 & R8 & R8.5 & & R6 & R7 & R8 & R8.5 & \\
\hline & & & & & $-\mathrm{g} \mathrm{m}^{-2}$ & & & & & \\
\hline Erect determinate & $5.5 \mathrm{a}$ & $5.9 \mathrm{a}$ & $6.5 \mathrm{a}$ & $6.9 \mathrm{a}$ & $\begin{array}{c}1998 \\
5.3 \mathrm{a}\end{array}$ & $0.35 \mathrm{a}$ & $0.50 \mathrm{a}$ & $0.60 \mathrm{a}$ & $0.79 \mathrm{~b}$ & $0.61 \mathrm{a}$ \\
\hline Erect indeterminate & $4.4 \mathrm{~b}$ & $5.1 \mathrm{a}$ & $6.2 \mathrm{a}$ & $6.4 \mathrm{~b}$ & $5.5 \mathrm{a}$ & $0.39 \mathrm{a}$ & $0.51 \mathrm{a}$ & $0.75 \mathrm{a}$ & $0.89 \mathrm{a}$ & $0.74 \mathrm{a}$ \\
\hline Prostrate indeterminate & $3.8 \mathrm{~b}$ & $5.0 \mathrm{a}$ & $6.3 \mathrm{a}$ & $6.1 \mathrm{~b}$ & $5.3 \mathrm{a}$ & $0.33 \mathrm{a}$ & $0.46 \mathrm{a}$ & $0.70 \mathrm{a}$ & $0.79 \mathrm{~b}$ & $0.69 \mathrm{a}$ \\
\hline Mean & $4.4 \mathrm{C}$ & $5.2 \mathrm{~B}$ & $6.3 \mathrm{~A}$ & $6.4 \mathrm{~A}$ & 5.3 & $0.36 \mathrm{D}$ & $0.49 \mathrm{C}$ & $0.69 \mathrm{~B}$ & $0.83 \mathrm{~A}$ & 0.69 \\
\hline $\mathrm{F}$ test for cultivar & $2.90^{*}$ & 1.27 & 0.67 & $2.31^{*}$ & 0.89 & 0.81 & 1.08 & 1.48 & $2.25^{*}$ & 2.04 \\
\hline CV (\%) & 29.02 & 31.05 & 23.80 & 19.64 & 18.72 & 33.47 & 32.10 & 26.26 & 19. 10 & 16.27 \\
\hline Erect determinate & $3.6 \mathrm{a}$ & $5.2 \mathrm{a}$ & $5.0 \mathrm{a}$ & $6.0 \mathrm{a}$ & $\begin{array}{l}1999 \\
4.9 \mathrm{a}\end{array}$ & $0.30 \mathrm{~b}$ & $0.42 \mathrm{~b}$ & $0.43 \mathrm{a}$ & $0.48 \mathrm{a}$ & $0.49 \mathrm{a}$ \\
\hline Erect indeterminate & $4.2 \mathrm{a}$ & $6.0 \mathrm{a}$ & $4.8 \mathrm{a}$ & $5.2 \mathrm{~b}$ & $4.2 \mathrm{~b}$ & $0.38 \mathrm{a}$ & $0.58 \mathrm{a}$ & $0.45 \mathrm{a}$ & $0.44 \mathrm{a}$ & $0.44 \mathrm{a}$ \\
\hline Prostrate indeterminate & $4.3 \mathrm{a}$ & $6.7 \mathrm{a}$ & $4.7 \mathrm{a}$ & $5.2 \mathrm{~b}$ & $4.4 \mathrm{~b}$ & $0.37 \mathrm{a}$ & $0.58 \mathrm{a}$ & $0.43 \mathrm{a}$ & $0.47 \mathrm{a}$ & $0.45 \mathrm{a}$ \\
\hline Mean & $4.1 \mathrm{D}$ & $6.0 \mathrm{~A}$ & $4.8 \mathrm{C}$ & $5.4 \mathrm{~B}$ & 4.4 & $0.36 \mathrm{C}$ & $0.54 \mathrm{~A}$ & $0.44 \mathrm{~B}$ & $0.46 \mathrm{~B}$ & 0.45 \\
\hline $\mathrm{F}$ test for cultivar & 1.72 & 1.42 & 0.77 & $2.40^{* *}$ & $2.20^{*}$ & $2.25^{*}$ & $2.78^{* *}$ & 0.85 & $2.62^{* *}$ & 1.79 \\
\hline CV (\%) & 26.51 & 28.53 & 23.12 & 19.12 & 17.51 & 24.00 & 22.31 & 24.59 & 17.53 & 18.69 \\
\hline
\end{tabular}

(1) R6, R7, R8, R8.5: growth stages of full flowering, pod setting, beginning of pod filling, and mid-pod filling, respectively. For each year, lowercase letters compare growth habits, and capital letters compare growth stages; means followed by the same letter do not differ by the Tukey test $(\mathrm{p}<0.05) .{ }^{*},{ }^{* *},{ }^{* * *} \mathrm{~F}$ test significant at $0.05,0.01$ and 0.001 probability levels. 
1998, whereas in 1999 determinate cultivars accumulated more $\mathrm{N}$ in grains (Table 3 ). There was no significant difference among cultivars in grain $\mathrm{P}$ content in both years.

A combined analysis over years of the nine cultivars common to both experiments revealed that at $\mathrm{R} 6$ root bean mass was similar in both years, but at R7 root growth was higher in 1998 than in 1999 (Figure 3). The accumulation of biomass, $\mathrm{N}$ and $\mathrm{P}$ in shoots at R6 and R7 were similar in both years, whereas at R8 and R8.5, bean plants accumulated more biomass, $\mathrm{N}$ and $\mathrm{P}$ in shoots in 1998 than in 1999. The higher accumulation of biomass and nutrients during pod filling was associated with a $57 \%$ higher grain yield in 1998 than in 1999, and also with higher grain $\mathrm{N}$ and $\mathrm{P}$ contents in 1998 (Figure 3).
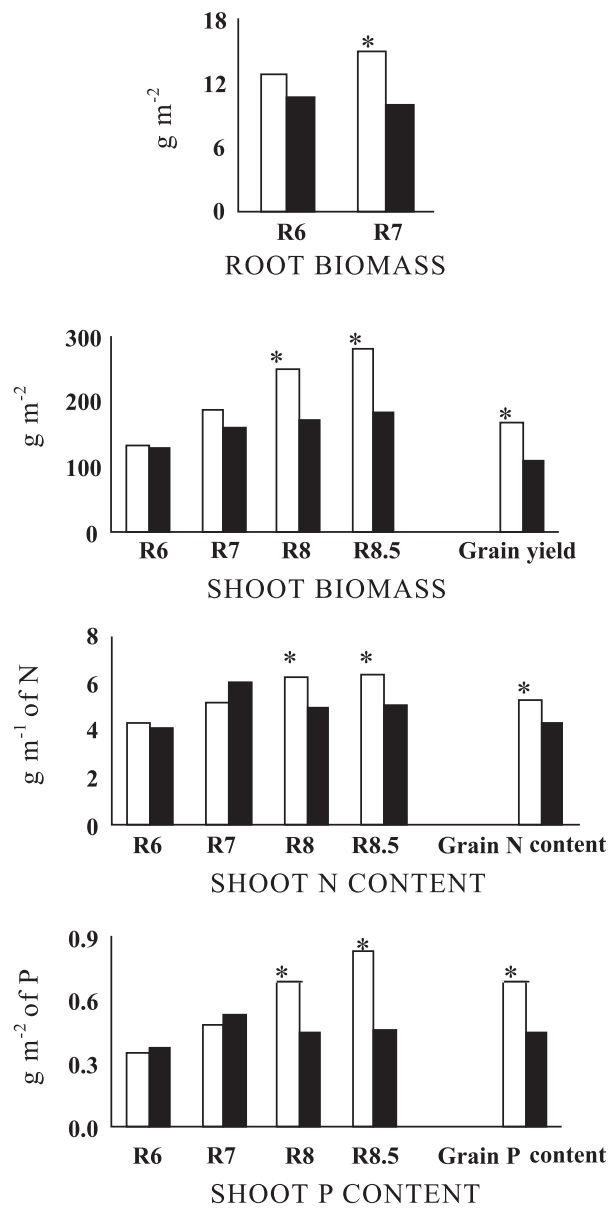

Figure 3. Combined analysis over years of root mass at two growth stages, shoot mass at four growth stages, grain yield at maturity, shoot $\mathrm{N}$ and $\mathrm{P}$ contents at four growth stages, and grain $\mathrm{N}$ and $P$ contents at maturity, of nine common bean cultivars grown in two field experiments: 1998 $(\square)$ and 1999 ( $\square)$; asterisks indicate significant difference between years ( $F$ test, $p<0.05$ ). R6, R7, R8, R8.5: growth stages of full flowering, pod setting, beginning of pod filling, and mid-pod filling, respectively.
In 1998 grain yield was not related to days to harvest, whereas in 1999 grain yield was negatively correlated with days to flowering and maturity (Table 4), with early cultivars yielding more than late cultivars. In both years, grain yield was not correlated with shoot mass at R6 and R7, nor with root mass at R6 (Table 4). Grain yield was correlated with shoot mass at R8 in 1999 but not in 1998, and with shoot mass at R8.5 in both years. Grain yield correlated with root mass at R7 in both years. In 1999 grain yield was positively correlated with shoot $\mathrm{N}$ content at R8.5, but negatively correlated with shoot $\mathrm{N}$ concentration at R8.5. Grain yield was negatively correlated with shoot $\mathrm{P}$ concentration at R6 in 1998, and at R7 and R8.5 in 1999. At other stages, the accumulation of $\mathrm{N}$ and $\mathrm{P}$ in shoots was not related to grain yield (Table 4).

Path coefficient analysis indicated differences between years regarding the effects of evaluated traits on grain yield (Table 5). In 1998, there were direct effects of root mass at R7 and of shoot mass at R8.5 on grain yield, with only small effects on shoot $\mathrm{N}$ and $\mathrm{P}$ accumulation. In 1999, root mass had a total positive effect on grain yield, and shoot mass at R8.5 had a direct effect on grain yield. In spite of the small total effect of shoot $\mathrm{N}$ and $\mathrm{P}$ content at R8.5 on grain

Table 4. Coefficients of simple correlation between grain yield and traits related to biomass and nutrient accumulation of common bean cultivars grown in two field experiments (1998 and 1999)

\begin{tabular}{|c|c|c|}
\hline Grain yield versus $^{(1)}$ & 1998 & 1999 \\
\hline Days to flowering & -0.202 & $-0.319 * *$ \\
\hline Days to maturity & -0.039 & $-0.224^{*}$ \\
\hline Shoot mass at R6 & 0.019 & 0.032 \\
\hline Root mass at R6 & -0.017 & -0.068 \\
\hline Shoot mass at R7 & 0.167 & 0.165 \\
\hline Root mass at $\mathrm{R} 7$ & $0.352^{*}$ & $0.284^{*}$ \\
\hline Shoot mass at $R 8$ & 0.141 & $0.271^{*}$ \\
\hline Shoot mass at R8.5 & $0.453^{* *}$ & $0.357 * *$ \\
\hline Shoot $N$ content at $R 6$ & 0.108 & 0.061 \\
\hline Shoot $N$ concentration at $R 6$ & 0.109 & 0.057 \\
\hline Shoot $N$ content at $R 7$ & 0.184 & 0.075 \\
\hline Shoot $\mathrm{N}$ concentration at $\mathrm{R} 7$ & 0.032 & -0.065 \\
\hline Shoot $N$ content at $R 8$ & 0.184 & 0.215 \\
\hline Shoot $\mathrm{N}$ concentration at $\mathrm{R} 8$ & 0.007 & -0.067 \\
\hline Shoot $\mathrm{N}$ content at $\mathrm{R} 8.5$ & 0.185 & $0.289^{*}$ \\
\hline Shoot $N$ concentration at $R 8.5$ & 0.031 & $-0.257^{*}$ \\
\hline Shoot $\mathrm{P}$ content at $\mathrm{R} 6$ & -0.128 & -0.032 \\
\hline Shoot $\mathrm{P}$ concentration at $\mathrm{R} 6$ & $-0.320^{*}$ & -0.146 \\
\hline Shoot $\mathrm{P}$ content at $\mathrm{R} 7$ & 0.021 & -0.019 \\
\hline Shoot $\mathrm{P}$ concentration at $\mathrm{R} 7$ & -0.179 & $-0.257^{*}$ \\
\hline Shoot $P$ content at $R 8$ & 0.129 & 0.114 \\
\hline Shoot $\mathrm{P}$ concentration at $\mathrm{R} 8$ & -0.053 & -0.201 \\
\hline Shoot $P$ content at $R 8.5$ & 0.189 & 0.144 \\
\hline Shoot $\mathrm{P}$ concentration at $\mathrm{R} 8.5$ & 0.269 & $0.350^{* *}$ \\
\hline
\end{tabular}

(1) R6, R7, R8, R8.5: growth stages of full flowering, pod setting, beginning of pod filling, and mid-pod filling, respectively.

*, **: Significant at 0.05 and 0.01 probability levels by t test. 
Table 5. Path coefficient analysis of the effects of biomass traits on grain yield of common bean cultivars grown in two field experiments (1998 and 1999); analysis performed with standardized variables

\begin{tabular}{|c|c|c|}
\hline Type of effect ${ }^{(1)}$ & 1998 & 1999 \\
\hline \multicolumn{3}{|l|}{ Model 1} \\
\hline Direct effect of root mass at R7 & $0.358 *$ & 0.090 \\
\hline Indirect effect via shoot mass at R8.5 & 0.001 & 0.216 \\
\hline Indirect effect via shoot $\mathrm{P}$ content at $\mathrm{R} 8.5$ & -0.007 & -0.021 \\
\hline Total & $0.352 *$ & $0.284^{*}$ \\
\hline Direct effect of shoot mass at R8.5 & 0.453 * & $0.524 *$ \\
\hline Indirect effect via root mass at $\mathrm{R} 7$ & 0.001 & 0.037 \\
\hline Indirect effect via shoot $\mathrm{P}$ content at $\mathrm{R} 8.5$ & 0.000 & -0.204 \\
\hline Total & $0.453^{*}$ & 0.357 * \\
\hline Direct effect of shoot $\mathrm{P}$ content at R8.5 & -0.035 & $-0.265^{*}$ \\
\hline Indirect effect via root mass at $\mathrm{R} 7$ & 0.070 & 0.007 \\
\hline Indirect effect via shoot mass at R8.5 & -0.001 & $0.402 *$ \\
\hline Total & 0.035 & 0.144 \\
\hline \multicolumn{3}{|l|}{ Model 2} \\
\hline Direct effect of root mass at $R 7$ & $0.345^{*}$ & 0.135 \\
\hline Indirect effect via shoot mass at $\mathrm{R} 8.5$ & 0.001 & 0.229 \\
\hline Indirect effect via shoot $\mathrm{N}$ content at $\mathrm{R} 8.5$ & 0.006 & -0.079 \\
\hline Total & $0.352 *$ & $0.284^{*}$ \\
\hline Direct effect of shoot mass at R8.5 & $0.448^{*}$ & 0.556 * \\
\hline Indirect effect via root mass at $\mathrm{R} 7$ & 0.001 & 0.055 \\
\hline Indirect effect via shoot $\mathrm{N}$ content at $\mathrm{R} 8.5$ & 0.005 & $-0.254^{*}$ \\
\hline Total & $0.453 *$ & $0.357^{*}$ \\
\hline Direct effect of shoot $\mathrm{N}$ content at R8.5 & 0.027 & $-0.271^{*}$ \\
\hline Indirect effect via root mass at R7 & 0.073 & 0.039 \\
\hline Indirect effect via shoot mass at $\mathrm{R} 8.5$ & 0.086 & 0.521 * \\
\hline Total & 0.185 & 0.289 * \\
\hline
\end{tabular}

yield, in 1999 there were indirect positive effects of shoot $\mathrm{N}$ and $\mathrm{P}$ contents through shoot mass at R8.5 (Table 5).

\section{DISCUSSION}

The lower grain yield in 1999 as compared to 1998 (Table 2) cannot be explained by mean air temperature and relative humidity, which were very similar during both experiments. A continuous $\mathrm{N}$ supply in 1998 by green manure incorporated before planting may be associated to the higher grain yield in this year, the excellent visual aspect of the crop confirming the improved N nutrition. Additionally, rust occurrence in 1999 certainly contributed to reduce yield. The disease might also explain the superior performance of determinate cultivars in 1999, as it limited seed filling of late indeterminate cultivars (Table 2). Lynch \& White (1992) also observed marked differences in $\mathrm{N}$ budget of common bean cultivars between two field experiments with planting dates only 20 days apart.

Both field experiments had low coefficients of variation (always lower than $23 \%$ ) for traits of biomass accumulation (Table 2). The sample unit of $1 \mathrm{~m}$ harvested plants from alternate rows prevented the inference of biomass sampling with consecutive samplings and also with grain yield evaluation (Figure 1) and ensured a strict control of plant growth measurements. Therefore, the lack of significant correlation between grain yield and some evaluated traits could not be ascribed to high experimental errors. The similar coefficients of simple correlation and path analysis in both experiments (Tables 4 and 5) made results even more meaningful, in spite of the distinct grain yield levels (Table 2).

Grain yield did not correlate with shoot biomass accumulated at the stages of flowering or pod setting in both years (Table 4). This lack of significant correlation between shoot biomass at flowering and grain yield in common bean has also been reported in previous studies (Stone \& Pereira, 1994; Yan et al., 1995; Araújo et al., 2000). Pires et al. (2005) also observed that the yield potential of five soybean cultivars estimated at flowering did not correlate with grain yield at maturity. According to Wallace (1985), the complex modulation of days-to-flowering in response to photoperiod and temperature under different environments, that often induces opposite effects on bean grain yield, leads some investigators to conclude that yield is positively correlated with total plant biomass, whereas others emphasize the merit of biomass partitioning for determining grain yield.

Shoot biomass correlated with grain yield only at pod filling stages (Table 4). The combined analysis of the nine cultivars common to both experiments indicated that bean produced similar shoot biomass until pod setting in both years, but during pod filling plants growing in 1998 accumulated more biomass, $\mathrm{N}$ and $\mathrm{P}$ in shoots, which resulted in higher grain yield in 1998 (Figure 3). Therefore, the marked differences in grain yield between the two years could only be predicted through shoot biomass measurements performed during pod filling. Pereira et al. (1989) also verified that shoot mass of field-grown bean lines increased throughout the growth cycle, and that larger differences in shoot mass among lines were found at later growth stages. In 1998, the amount of biomass, $\mathrm{N}$ and $\mathrm{P}$ in shoots increased continuously after flowering, confirming that bean is able to maintain growth and nutrient acquisition during the reproductive development (Araújo et al., 2000). However, in 1999 shoot growth ceased between R7 and R8, and the amounts of $\mathrm{N}$ and $\mathrm{P}$ in shoots of indeterminate cultivars decreased (Tables 2 and 3), partially due to rust incidence that provoked some leaf senescence. This emphasizes that the comprehension of growth and nutrient acquisition of common bean requires plant evaluations at different growth stages (Araújo \& Teixeira, 2000).

The higher grain yield in 1998 could be associated with a continuous accumulation of biomass, $\mathrm{N}$ and $\mathrm{P}$ during pod filling, whereas in 1999 a weaker growth 
and nutrient accumulation after pod setting was related with a lower grain yield and amounts of $\mathrm{N}$ and $\mathrm{P}$ in grains (Figure 3). Westermann et al. (1985) also observed that two bean lines with similar patterns of growth and $\mathrm{N}$ accumulation during vegetative development had distinct final grain yields. The high $\mathrm{N}$ requirement of bean seed induces $\mathrm{N}$ remobilization from vegetative tissues, and a concomitant degradation of leaf proteins inducing leaf senescence that results in declined canopy photosynthesis (Lynch $\&$ White, 1992). Evidence of a positive relation between the length of the pod filling period, that could provide larger amounts of photosynthates for growing seeds, and grain yield on common bean, suggests that extended leaf area duration would be required for highyielding bean cultivars (Ranalli \& Cubero, 1997). This indicates that grain yield of common bean is not intrinsically associated with the vegetative vigor at flowering, and that some mechanisms during early pod filling can strongly influence the final crop yield. The continuous acquisition of $\mathrm{N}$ and $\mathrm{P}$ during later growth stages most likely plays a key role in improving grain yield of common bean.

Relationships between grain yield and $\mathrm{N}$ and $\mathrm{P}$ shoot accumulation were weak (Table 4). This can be partially explained by the narrower cultivar variability for nutrient accumulation than for biomass in shoots and grains (Tables 2 and 3). In 1998 no effect of shoot $\mathrm{N}$ and $\mathrm{P}$ contents on grain yield was identified, whereas in 1999 grain yield was negatively correlated with $\mathrm{N}$ and $\mathrm{P}$ concentrations in shoots at R8.5 (Table 4), and the amounts of $\mathrm{N}$ and $\mathrm{P}$ in shoots exerted an indirect positive effect on grain yield via shoot mass at R8.5 (Table 5). Therefore, in the experiment with lowest level of productivity (1999) some phenotypic variation in grain yield was associated with shoot $\mathrm{N}$ and $\mathrm{P}$ at mid-pod filling. Since low tissue nutrient concentration can be roughly interpreted as a higher nutrient use efficiency for biomass production, in 1999 grain yield was partially associated with the $\mathrm{N}$ and $\mathrm{P}$ use efficiency, where $\mathrm{N}$ and $\mathrm{P}$ shoot concentrations in high yielding cultivars were lowest at mid-pod filling. The $\mathrm{P}$ utilization rate for biomass production in bean cultivars differed under P-limiting conditions (Araújo \& Teixeira, 2000), and some variation among bean cultivars for grain yield in two field experiments was associated with lower seed $\mathrm{N}$ and $\mathrm{P}$ concentrations (Araújo \& Teixeira, 2003). Hence, the nutrient use efficiency is likely to play a role for greater bean growth and yield under conditions of limited nutrient availability.

The earliest significant correlation with grain yield was observed for root biomass (Table 4) which also indicated the differences between years for crop productivity earliest (Figure 3). Root mass at R7 had a positive effect on grain yield in both years, by a direct effect in 1998 and by an indirect effect via shoot mass at R8.5 in 1999 (Table 5). Root systems of bean lines differing in drought tolerance reached different soil depths; these differences were associated with crop growth and grain yield (Sponchiado et al., 1989). Basal root and taproot mass of bean lines increased until seed initiation but decreased during intense pod filling, suggesting that root senescence in bean begins before physiological maturity (Stoffella et al., 1979). The estimates of broad-sense heritability of common bean root mass and root area at pod setting were relatively high, with predominance of the additive portion of the heritable variation, indicating that the genetic selection for greater root system among progeny lines is possible (Araújo et al., 2005). In view of the numerous important functions of the root system, such as water and nutrient uptake, soil anchorage, and biotic interactions with the rhizosphere, it is suggested that the establishment of a profuse root system during pod setting is necessary for higher bean grain yields.

\section{CONCLUSIONS}

1. In two field experiments, grain yield of common bean cultivars did not correlate with shoot mass at flowering or pod setting, whereas grain yield correlated with shoot mass at mid-pod filling and with root mass at pod setting.

2. In the experiment with higher productivity, grain yield of bean cultivars was not associated with $\mathrm{N}$ and $\mathrm{P}$ shoot accumulation, whereas in the experiment with lower productivity some phenotypic variation in grain yield was associated with the amounts of $\mathrm{N}$ and $\mathrm{P}$ in shoots at mid-pod filling.

3 . The accumulation of biomass, $\mathrm{N}$ and $\mathrm{P}$ in shoots of bean plants at flowering and pod setting did not differ between the two field experiments, but in the experiment with higher productivity levels bean accumulated more root mass at pod setting and also more biomass, $\mathrm{N}$ and $\mathrm{P}$ in shoots at pod filling.

\section{LITERATURE CITED}

ARAÚJO, A.P. Analysis of variance of primary data on plant growth analysis. Pesq. Agropec. Bras., 38:1-10, 2003.

ARAÚJO, A.P. \& TEIXEIRA, M.G. Ontogenetic variations on absorption and utilization of phosphorus in common bean cultivars under biological nitrogen fixation. Plant Soil, 225:1-10, 2000

ARAÚJO, A.P. \& TEIXEIRA, M.G. Nitrogen and phosphorus harvest indices of common bean cultivars: Implications for yield quantity and quality. Plant Soil, 257:425-433, 2003.

ARAÚJO, A.P.; ANTUNES, I.F. \& TEIXEIRA, M.G. Inheritance of root traits and phosphorus uptake in common bean (Phaseolus vulgaris L.) under limited soil phosphorus supply. Euphytica, 145:33-40, 2005. 
ARAÚJO, A.P.; TEIXEIRA, M.G. \& ALMEIDA, D.L. Growth and yield of common bean cultivars at two soil phosphorus levels under biological nitrogen fixation. Pesq. Agropec. Bras., 35:809-817, 2000.

FERNÁNDEZ, F.C.; GEPTS, P. \& LÓPEZ, M. Etapas de desarrollo en la planta de frijol. In: LÓPEZ, M.; FERNÁNDEZ, F.; VAN SCHOONHOVEN, A., eds.. Frijol: Investigación y producción. Cali, CIAT, 1985. p.61-78.

KELLY, J.D.; KOLKMAN, J.M. \& SCHNEIDER, K. Breeding for yield in dry bean (Phaseolus vulgaris L.). Euphytica, 102:343-356, 1998.

LAING, D.R.; JONES, P.G. \& DAVIS, J.H.C. Common bean (Phaseolus vulgaris L.). In: GOLDSWORTHY, P.R. \& FISHER, N.M., eds. The physiology of tropical field crops. New York, John Wiley, 1984. p.305-351.

LYNCH, J. \& WHITE, J.W. Shoot nitrogen dynamics in tropical common bean. Crop Sci., 32:392-397, 1992.

MUNIER-JOLAIN, N.G. \& SALON, C. Are the carbon costs of seed production related to the quantitative and qualitative performance? An appraisal for legume and other crops. Plant Cell Environ., 28:1388-1395, 2005.

PEREIRA, P.A.A.; BURRIS, R.H. \& BLISS, F.A. ${ }^{15}$ Ndetermined dinitrogen fixation potential of genetically diverse bean lines (Phaseolus vulgaris L.). Plant Soil, 120:171-179, 1989.

PIRES, J.L.F.; COSTA, J.A.; RAMBO, L. \& FERREIRA, F.G. Métodos para a estimativa do potencial de rendimento da soja durante a ontogenia. Pesq. Agropec. Bras., 40:337$344,2005$.

RANALLI, P. \& CUBERO, J.I. Bases for genetic improvement of grain legumes. Field Crops Res., 53:69-82, 1997.

RICHARDS, R.A. Selectable traits to increase crop photosynthesis and yield of grain crops. J. Exper. Bot., 51:447-458, 2000 .
SCHILTZ, S.; MUNIER-JOLAIN, N.; JEUDY, C.; BURSTIN, J. \& SALON, C. Dynamics of exogenous nitrogen partitioning and nitrogen remobilization from vegetative organs in pea revealed by ${ }^{15} \mathrm{~N}$ in vivo labeling throughout seed filling. Plant Physiol., 137:1463-1473, 2005.

SCULLY, B.T. \& WALLACE, D.H. Variation in and relationship of biomass, growth rate, harvest index, and phenology to yield of common bean. J. Am. Soc. Hortic. Sci., 115:218$225,1990$.

SNAPP, S.S. \& LYNCH, J.P. Phosphorus distribution and remobilization in bean plants as influenced by phosphorus nutrition. Crop Sci., 36:929-935, 1996.

SPONCHIADO, B.N.; WHITE, J.W.; CASTILLO, J.A. \& JONES, P.G. Root growth of four common bean cultivars in relation to drought tolerance in environments with contrasting soil types. Exper. Agric., 25:249-257, 1989.

STOFFELLA, P.J.; SANDSTED, R.F.; ZOBEL, R.W. \& HYMES, W.L. Root characteristics of black beans. II. Morphological differences among genotypes. Crop Sci., 19:826-830, 1979.

STONE, L.F. \& PEREIRA, A.L. Sucessão arroz-feijão irrigados por aspersão: Efeitos de espaçamento entre linhas, adubação e cultivar no crescimento, desenvolvimento radicular e consumo d'água do feijoeiro. Pesq. Agropec. Bras., 29:939-954, 1994.

TAR'AN, B.; MICHAELS, T.E. \& PAULS, K.P. Genetic mapping of agronomic traits in common bean. Crop Sci., 42:544556,2002 .

WALLACE, D.H. Physiological genetics of plant maturity, adaptation and yield. Plant Breeding Rev., 3:21-167, 1985.

WESTERMANN, D.T.; PORTER, L.K. \& O'DEEN, W.A. Nitrogen partitioning and mobilization patterns in bean plants. Crop Sci., 25:225-229, 1985.

YAN, W. \& WALLACE, D.H. Breeding for negatively associated traits. Plant Breeding Rev., 13:141-177, 1995.

YAN, X.; BEEBE, S.E. \& LYNCH, J.P. Genetic variation for phosphorus efficiency of common bean in contrasting soil types: II. Yield response. Crop Sci., 35:1094-1099, 1995. 